\title{
Physicochemical Properties and Pesticide Residues in Okra Fruits (Abelmoschus esculentus L.)
}

\author{
Polash Nandi, Md. Mazharul Islam, Abida Sultana* and Mohammad Shoeb \\ Department of Chemistry, University of Dhaka, Dhaka-1000, Bangladesh
}

(Received : 1 July 2020; Accepted : 4 October 2020)

\begin{abstract}
Vegetable acts as major valuable source of nutrients. Among different vegetables, okra was analyzed to study moisture content, ash content, soluble dietary fiber (SDF), total carbohydrates, and micro-minerals, fatty acid compositions and pesticide residues. Fatty acid compositions were studied by gas chromatograph equipped with a flame ionization detector (GC-FID) while, gas chromatograph equipped with electron capture detector GC-ECD was used for analysis of pesticide residues. Total carbohydrate content was determined by ultraviolet-visible spectrophotometer. The amount of soluble dietary fiber was estimated by acid extraction method. $\mathrm{Fe}, \mathrm{Cu}$ and $\mathrm{Zn}$ content were analyzed by atomic absorption spectroscopy (AAS). The relative percentage of fatty acids were found to be palmitic, cis-9-oleic, linoleic, linolenic and arachidic acid in a range of $0.27-1.35,3.78-6.32,30.67-38.44,2.13-4.85$ and $1.29-3.17 \%$, respectively. Residual diazinon, chlorpyrifos, fenvalerate, cypermethrin and quinalphos were not found to be present in any sample. Total carbohydrate, SDF, moisture and ash content in fresh okra fruits were found to be 6.01- 6.09, 3.35 - 3.50, $88.02-91.84$ and $1.72-2.04 \%$, respectively. The amount of $\mathrm{Fe}, \mathrm{Cu}$ and $\mathrm{Zn}$ was 11.41-11.43, 1.78 -1.85 and 8.56 - $9.05 \mathrm{mg}$ per $100 \mathrm{~g}$ sample, respectively.
\end{abstract}

Keywords: Fatty acids, Nutrients, Pesticides, Physicochemical properties

\section{Introduction}

Vegetables are the important food items for human for the maintenance of health and prevention of disease. Okra (Abelmoschus esculentus) is the most prominent one vegetable of Malvaceae family for human beings throughout the world, especially in tropical and sub-tropical parts, including Bangladesh. ${ }^{1,2}$ It is also known as lady's finger and locally called "Dharos" or "Vendi" or "Gumbo" and an economically important vegetable crop widely. ${ }^{3,4}$ Protein, minerals, vitamins and roughage are of the important ingredient found in okra as a vegetable. ${ }^{5}$ It can be cultivated in both the garden crop and commercial firming as a multipurpose crop because of its different uses of the buds, flowers, pods, seeds and stems .2, 6,7 The entire plant is edible and, traditionally, the raw fruits are used not only as vegetable but also as salads, making pickles, soups etc. ${ }^{8,9} \beta$ Glucans, pectic substances, gums and mucilage are present in okra fruits as soluble dietary fiber (SDF). ${ }^{10} \mathrm{SDF}$ imparts beneficial effects on decreasing serum cholesterol and blood sugar level. The risks of cardiovascular diseases are also minimized by taking diet high in SDF. ${ }^{11}$ Okra fruits contain various types of fatty acids. The linoleic acid (omega-6) and linolenic acid (omega-3) are essential fatty acids. Besides stearic acid, oleic acid, arachidic acid, margaric acid, pentadecylic acid, myristic acid, palmitic acid etc are also present in okra fruit. Fatty acids are used in cosmetics industry because of skin care properties such as antiinflammatory, acne-reduction and moisture retention properties and play important role in lowering of blood pressure, relaxation of coronary arteries, and inhibition of platelet aggregatio. ${ }^{12,13}$ Minerals are naturally occurring inorganic substances with a definite chemical composition. The function of the human body, the structure of skeleton, catalytic activity etc. are assisted by minerals. In the metabolism of almost all living organisms, iron plays a key role. Especially, in humans, iron is an essential component of hundreds of proteins and enzymes. ${ }^{14}$ Copper $(\mathrm{Cu})$ is an essential trace element for humans and animals. In oxidation-reduction reactions $\mathrm{Cu}$ plays an important role by the formation of the cuprous $\left(\mathrm{Cu}^{+}\right)$and the cupric $\left(\mathrm{Cu}^{2+}\right)$ ions. Zinc plays an important role in the structure of proteins and cell membranes. ${ }^{10}$ Moisture content is an important indicator of food shelf-life since it has an important relationship between conservation and the chemical, physical and microbiological changes during the storage of foods regardless in a wet or dry state. ${ }^{15}$ Ash content also is essential to a food's nutrition and longevity. The higher the water content of foods, the more it is susceptible to the interactions with microbes and its environment. The present study was also focused to study the nutrient content, fatty acid composition and pesticides residues in okra fruit. In every country the information about food composition is necessary to assess the diet quality and development for providing a useful guideline for the field of public health nutrition. In this regard to improve the reliable data on food in Bangladesh, the okra fruit was aimed to study.

\section{Experimental}

\section{Sample Collection}

Fresh okra fruit samples were collected from different local markets of Dhaka city (Table 1) and transferred to the laboratory for the analysis. The samples were chopped and thoroughly blended to obtain a homogeneous representative sample and stored in a refrigerator at $-20^{\circ} \mathrm{C}$ for further analysis.

\section{Chemicals and Reagents}

Analytical grade solvents purchased from Merck, Germany such as extra pure n-hexane, ethyl acetate and DCM. $\mathrm{H}_{2} \mathrm{SO}_{4}$ (98\%, w/w, BDH, U.K), phenol (Merck, Mumbai, India), methanol (99.5\%, w/w, Sigma Aldrich), ethanol (99.8\% w/v, Sigma Aldrich), $\mathrm{NaOH}$ (BDH, U.K) and $\mathrm{BF}_{3}-\mathrm{CH}_{3} \mathrm{OH}$ 
complex (Merck, Germany) were used during the work. Anhydrous $\mathrm{MgSO}_{4}$, anhydrous $\mathrm{Na}_{2} \mathrm{SO}_{4}$ and $\mathrm{NaCl}$ of Merck, Germany; florisil from ACROS Organics, USA; Alumina from Merck, Germany; Charcoal from Uni-Chem, China were used. Analytical grade diazinon (97.5\% purity), quinalphos (98.4\%), chlorpyrifos (99.5\% purity), cypermethrin (91.9\% purity) and fenvalerate (98.5\% purity) purchased from Dr. Ehrenstorfer, Germany were used as pesticides standard.

\section{Instruments}

The experiment was carried out using oven and furnace (GSM 11/8 Hope Valley, S336RB, England), Analytical balance (model- AL 104, Company- Mettler Toledo, US), Double beam UV spectrophotometer (Model: UV-1800, Shimadzu), Gas chromatograph with a flame ionization detector (GC-FID, Shimadzu-2025), Gas chromatograph with electron capture detector (GC-ECD, Shimadzu-2030), pH meter (Model: Hanna pH 211) and Vortex machine (Cat/Art No 444-1372 (EU), Made in Germany) and Zeeman atomic absorption spectroscopy (GTA 120_AA240Z with PSD auto sampler, Varian, Australia).

\section{Preparation of Pesticides Standard Solutions}

Primary standard solutions of diazinon, chlorpyrifos, fenvalerate, cypermethrin and quinalphos were prepared separately in $100 \mathrm{~mL}$ volumetric flask with $\mathrm{n}$-hexane. For preparation of $100 \mathrm{ppm}$ standard solution $10 \mathrm{mg}$ of each standard compound was taken in $100 \mathrm{~mL}$ separate volumetric flask and dissolved in $\mathrm{n}$-hexane and up to marked. After serial dilution the working standard solutions of each of the standards were run into GC-ECD and calibration curves were made.

\section{Extraction and Estimation of Pesticides}

$10 \mathrm{~g}$ homogenized sample and $20 \mathrm{~mL}$ ethyl acetate were taken in a $50 \mathrm{~mL}$ Teflon tube and vortex for 2 min. $6 \mathrm{~g}$ $\mathrm{MgSO}_{4}$ and $1.5 \mathrm{~g} \mathrm{NaCl}$ were added which then vortex and centrifuged. The supernatant was evaporated in a rotary evaporator. The dried mass was dissolved in $5 \mathrm{ml} \mathrm{n}$-hexane and evaporated to complete dryness. This procedure was repeated for two times. Finally the dried mass was reconstituted in $2 \mathrm{~mL}$ of n-hexane. For additional clean-up, a glass column $(40 \mathrm{~cm}$ long \& $12 \mathrm{~mm}$ internal diameter) was packed with $10.5 \mathrm{~g}$ mixture of alumina, florisil and charcoal (10:10:1) with $\mathrm{n}$-hexane. Then $5 \mathrm{~g}$ of $\mathrm{Na}_{2} \mathrm{SO}_{4}$ was added to the column and equilibrated with $40 \mathrm{~mL}$ n-hexane. The extract in n-hexane was transferred to the equilibrated column and the column was washed with $20 \mathrm{~mL}$ of $\mathrm{n}$ hexane and eluted with $100 \mathrm{~mL}$ of DCM and collected in a round bottom flask. The eluent was concentrated to dryness. The dried mass was dissolved in $5 \mathrm{~mL} \mathrm{n}$-hexane and evaporated to complete dryness. This procedure was repeated for two times. Finally the dried mass was reconstituted in $4 \mathrm{~mL}$ of $\mathrm{n}$-hexane and transferred to a GC vial. GC-ECD was used for the determination of pesticide residues. A capillary column of $30 \mathrm{~m}$ length, $0.25 \mathrm{~mm}$ inner diameter, $35 \mathrm{~mm}$ external diameter and $0.25 \mu \mathrm{m}$ film thicknesses from Agilent, USA was used. Injector and detector temperature was set at 220 and $290^{\circ} \mathrm{C}$, respectively. Column flow rate was $1.0 \mathrm{~mL} / \mathrm{min}$, Nitrogen gas was used as career and make up gas, respectively. Injection volume was $1.0 \mu \mathrm{L}$, split-splitless mode was set and total program time was 20 min.

\section{Extraction and Estimation of Fatty Acids}

Sample $(10 \mathrm{~g})$ and $30 \mathrm{~mL}$-hexane were taken in round bottom flask and refluxed in boiling water bath for about an hour and the extract was collected. The procedure was repeated for three times. The extracts were combined and filtered through anhydrous $\mathrm{Na}_{2} \mathrm{SO}_{4}$. The filtrate was dried to a constant weight of oil. The oil from each sample was taken in a round bottom flask and $1 \mathrm{~mL}$ of alcoholic $0.5 \mathrm{M} \mathrm{NaOH}$ was added to it. Then the flask was shaken well and was kept in hot water bath $\left(95^{\circ} \mathrm{C}\right)$ in order to reflux for $30 \mathrm{~min}$. The aqueous layer was acidified with dilute $\mathrm{HCl}$ and partitioned with n-hexane. The organic phase was collected and evaporated by rotary evaporator until dryness. $1 \mathrm{~mL} \mathrm{BF}_{3}-$ $\mathrm{CH}_{3} \mathrm{OH}$ complex was added to the dry mass and was sonicated for $30 \mathrm{sec}$. Later the sample was heated in hot water bath for 30 minutes and the sample was again dried by rotary evaporator and then $2 \mathrm{~mL}$ of $\mathrm{n}$-hexane was added to the flask and was ultrasonicated. The volume was reduced to $0.5 \mathrm{~mL}$ and the sample was collected in a sample vial. Then the sample was injected to GC-FID. In GC-FID, separations were performed on HP-5 column ( $30 \mathrm{~m}$ in length, $0.25 \mathrm{~mm}$ in diameter and film thickness $0.25 \mu \mathrm{m})$. The temperature program in the oven was as followed: $140^{\circ} \mathrm{C}$ for $1 \mathrm{~min}$ (hold) was gradually increased by $7^{\circ} \mathrm{C} / \mathrm{min}$ to $270^{\circ} \mathrm{C}$ and was again hold for 10 min. Column flow rate of carrier gas $\left(\mathrm{N}_{2}\right)$ was 2 $\mathrm{mL} / \mathrm{min}$. As a fuel for FID, air and nitrogen gases were used. Injector and detector temperature was 280 and $290^{\circ} \mathrm{C}$, respectively. Injection volume was $1 \mu \mathrm{L}$. The mixtures of standard methyl ester of fatty acids were found to be gave chromatogram with separate peaks in different retention time. Sample was injected into the injector of GC at the same condition, as methyl ester of fatty acid standard and retention time of each fatty acid was compared.

\section{Estimation of Soluble Dietary Fiber}

The extraction of soluble dietary fiber (SDF) from okra fruit powder was carried out by conventional acid extraction method. Okra fruit powder $(10 \mathrm{~g})$ was taken in a flask and $200 \mathrm{~mL}$ distilled water was added to it. $\mathrm{pH}$ of the water adjusted to 2.0 with sulfuric acid. The mixture was stirred for 4 hours at $90^{\circ} \mathrm{C}$ in a water bath and filtered. The filtrate was concentrated and ethanol was added to a final concentration of $70 \%$ and precipitate was obtained. The ethanol precipitation process lasted for 1.0 hours and SDF was collected by centrifugation and dried at room temperature.

\section{Determination of Total Carbohydrate}

$2.0 \mathrm{mg}$ of D-glucose was weighted and taken in a $10.0 \mathrm{~mL}$ volumetric flask with $3.0 \mathrm{~mL}$ conc. $\mathrm{H}_{2} \mathrm{SO}_{4}$ and vortexed for $1 \mathrm{~min}$. Then it was diluted to mark by conc. $\mathrm{H}_{2} \mathrm{SO}_{4}$. After preparing the standard solution, various dilutions were made by pipetting a known volume of standard solution and 
marked by conc. $\mathrm{H}_{2} \mathrm{SO}_{4}$. The concentration of diluted standard solutions were $100,80,60,50,30$ and $15 \mathrm{mg} / \mathrm{L}$. $3.0 \mathrm{~mL}$ from each volumetric flask was taken in different test tube and $50 \mu \mathrm{L} 80 \%$ aqueous phenol was added in each test tube and vortexed for $1.0 \mathrm{~min}$. The $\lambda_{\max }$ of the working standard solutions were detected at $489 \mathrm{~nm}$ (figure 1). The total carbohydrates in okra fruit samples was determined by following the phenol-sulfuric acid test ${ }^{16}$ and calibration curve (figure 2) of standard D(+)-Glucose.

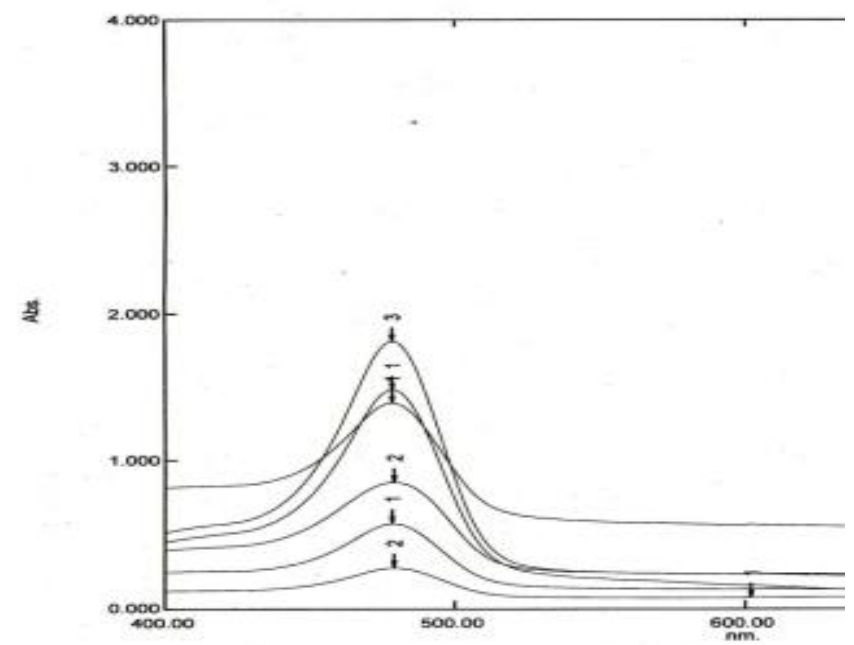

Fig. 1. UV-visible overlain spectrum of standard D-glucose.

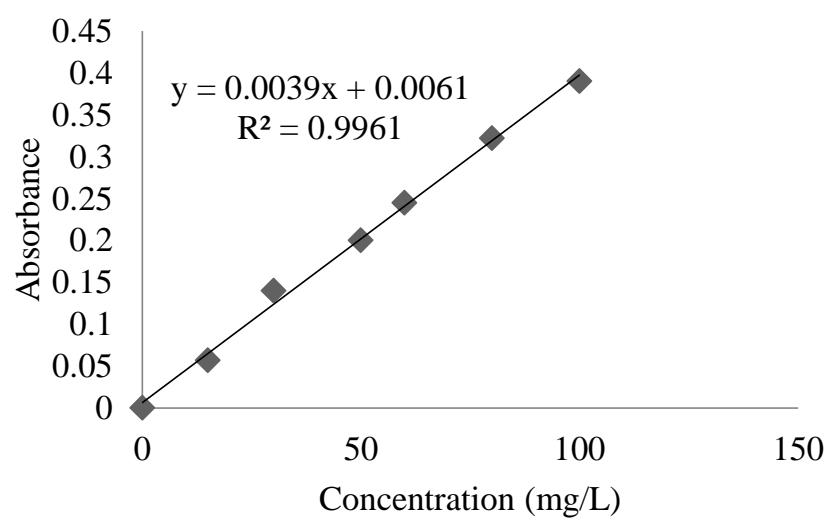

Fig. 2. The calibration curve of standard D-glucose.

\section{Moisture and Ash Content}

Moisture and ash content were determined by Association of Official Analytical Chemists method (AOAC; 1995). 10g of fresh okra fruit sample was taken in crucible and weighted. Then heated in oven at $105^{\circ} \mathrm{C}$ temperature for 4 hours and it was weighted again. Moisture content was obtained from the difference of weight. The crucible and content was transferred in muffle furnace and ignited at $700^{\circ} \mathrm{C}$ and let stayed overnight. The crucible and content was kept in desiccators. After cooling, it was weighted and result was calculated in $\mathrm{g} / 100 \mathrm{~g}$ sample.

\section{Sample Preparation and Minerals Analysis}

Minerals were analyzed in flame atomizer based atomic absorption spectrometry using hollow cathode lamp as a radiation source. Accurately $8.0 \mathrm{~g}$ of fruits powder was taken in a silica crucible and kept in a muffle furnace at $700^{\circ} \mathrm{C}$ for 4 hours. The heating process was repeated for three times after cooled down the sample to room temperature. The ash was then dissolved by adding conc. $\mathrm{HNO}_{3}$ and fill up the volumetric flask with deionized water. Then the sample was prepared to analyze minerals with the AAS.

\section{Results and Discussion}

Fresh fruits were used to analyze moisture, ash, fatty acid, total carbohydrate, soluble dietary fiber and minerals were estimated by dried powder of okra fruit.

\section{Moisture Content}

The mean value of moisture content was found to be in a range of $88.77 \pm 0.71$ to $90.16 \pm 1.62 \%$ in okra samples (Table 1). In 2016, Habtamu et al. reported that the water content in okra pod was found to be in the range of 87.98 to $90.60 \mathrm{~g} / 100 \mathrm{~g}^{17}{ }^{17}$ Javed et al, Eze et al. and Chanchal et al. reported that the moisture content in fresh okra samples was found to be $89.80 \pm 0.67,89.09 \pm 0.01$ and $90.19 \%$, respectively. ${ }^{18-20}$ The reported values are very close to the present study. In 2013, Uyoh et al. reported that moisture content is the index of food for microbial attack which makes the food susceptible and vulnerable to spoilage. ${ }^{21}$

\section{Ash Content}

Except the okra sample from Mohakhali market $(1.95 \pm$ $0.10 \%$ in sample $\mathrm{M})$ the rest three samples contain almost same amount $(1.84 \pm 0.09 \%$ in sample $\mathrm{K}, 1.87 \pm 0.08 \%$ in $\mathrm{K}_{\mathrm{p}}$ and $1.87 \pm 0.14 \%$ ) in sample $\mathrm{P}$ ) of ash (Table 1). In 2014, Emmanuel et al. reported the percentage of ash in the mature and young okra fruit at 1.18 and $1.34 \%$, respectively which is very close to this study with slight variation. $^{22}$ Peter et al. in 2019 also reported the ash content in fresh okra samples $1.17 \%$ that is few amount smaller than this study. ${ }^{23}$ Ash content is the indirect measuring index of the valuable mineral content present in the food. ${ }^{24,25}$ Present study reveals that the ash content in the fresh okra fruit was high that implies okra fruits contain more important minerals for physical development.

\section{$S D F$}

Due to soluble nature SDF can impart nutritional benefits. Plant cell wall is rich in dietary fiber so disintegration of the macromolecular structure of cell wall was done in order to obtain SDF. Acidic condition facilitates the degradation process and $\mathrm{pH} 2$ was adjusted to obtain the highest amount of SDF. The mean value of SDF was found to be $3.40 \pm 0.05$ to $3.46 \pm 0.04 \%$ in okra samples (Table 1). Sindhu et al. and Ikewuchi et al. reported the dietary fiber content was found 3.2 and $2.89 \mathrm{~g}$, respectively, per $100 \mathrm{~g}$ okra and these value is close to this research. ${ }^{26,27}$ Epidemiological studies hints that more consumption of fiber reduce the incidence of some diseases like colon cancer, high blood pressure, coronary heart disease, obesity, diabetes, and various digestive disorders. ${ }^{17,27}$ Thus, this study shows that okra fruits can be considered as an important source of dietary fiber. 
Table 1. Determination of moisture, ash and SDF content of okra fruits.

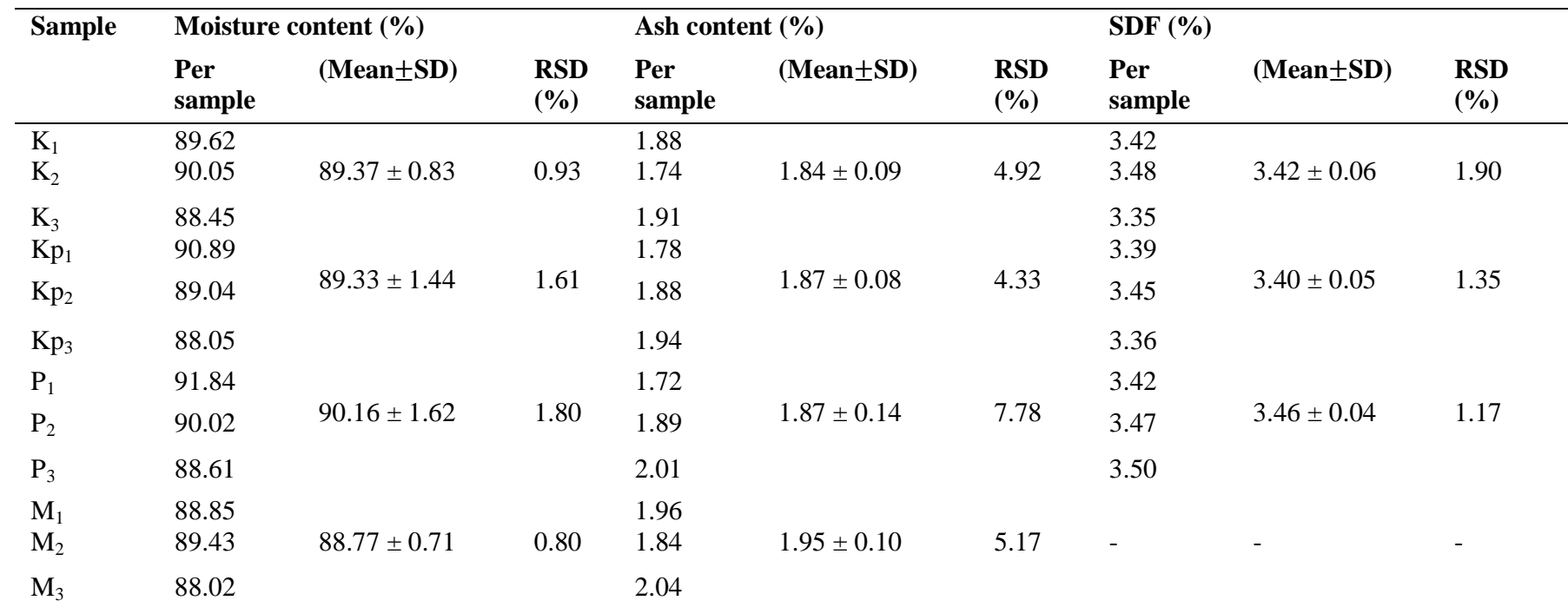

Notes: K- Karwan Bazar, Kp-Kaptan Bazar, P-Polashi Bazar and M-Mohakhali Bazar, “-” indicates Not studied, SD-Standard deviation \& RSD-Relative standard deviation

Table 2. Total carbohydrates, fatty acids composition and minerals content of okra fruits.

\begin{tabular}{|c|c|c|c|c|c|c|c|c|c|c|}
\hline \multirow[t]{2}{*}{ Sample } & \multicolumn{2}{|c|}{$\begin{array}{l}\text { Total carbohydrates } \\
(\mathrm{g} / \mathbf{1 0 0 g})\end{array}$} & \multicolumn{5}{|c|}{ Relative percentage of fatty acids composition (\%) } & \multicolumn{2}{|c|}{$\begin{array}{l}\text { Minerals }(\text { dry } \\
\text { basis })(\mathrm{mg} / \mathbf{1 0 0 g})\end{array}$} & \multirow{2}{*}{$\begin{array}{c}\text { weight } \\
\text { Zn }\end{array}$} \\
\hline & $($ Mean \pm SD $)$ & $\begin{array}{l}\text { RSD } \\
(\%)\end{array}$ & Palmitic & $\begin{array}{l}\text { cis-9- } \\
\text { oleic }\end{array}$ & Linoleic & Linolenic & Arachidic & $\mathbf{F e}$ & $\mathrm{Cu}$ & \\
\hline $\mathrm{K}_{1}$ & & & & & & & & - & - & - \\
\hline $\mathrm{K}_{2}$ & $6.09 \pm 0.74$ & 0.02 & 1.35 & 4.85 & 33.21 & 2.13 & 3.17 & - & - & - \\
\hline $\mathrm{K}_{3}$ & & & & & & & & 11.43 & 1.78 & 9.05 \\
\hline $\mathrm{Kp}_{1}$ & & & & & & & & - & - & - \\
\hline $\mathrm{Kp}_{2}$ & - & - & 0.27 & 3.78 & 38.44 & 3.31 & 1.29 & 11.41 & 1.85 & 8.56 \\
\hline $\mathrm{Kp}_{3}$ & & & & & & & & - & - & - \\
\hline $\mathrm{P}_{1}$ & & & & & & & & - & - & - \\
\hline $\mathrm{P}_{2}$ & $6.01 \pm 0.49$ & 0.01 & ND & 6.32 & 34.33 & 4.85 & 2.34 & - & - & - \\
\hline $\mathrm{P}_{3}$ & & & & & & & & - & - & - \\
\hline $\mathrm{M}_{1}$ & & & & & & & & - & - & - \\
\hline $\mathrm{M}_{2}$ & - & - & 0.95 & ND & 30.67 & 2.65 & 1.41 & - & - & - \\
\hline $\mathrm{M}_{3}$ & 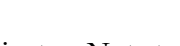 & & & & & & & - & - & - \\
\hline
\end{tabular}

\section{Pesticide Residues}

The samples were injected in GC-ECD for the sake of pesticides analysis. The retention time of each sample was not matching any retention time of standard pesticides. No such pesticide residue was found to present in okra fruit. But farmers used pesticides to control pests and herbs. Halflife of pesticides may be not as much as long. So, there is a little possibility that no pesticides were used during cultivation of okra fruits and other possibility that the pesticides were degraded to many others persistent or nonpersistent compounds.

\section{Carbohydrates}

Carbohydrates provide energy in the body. Okra fruits contain both edible and inedible carbohydrates. Amount of total carbohydrate was found to be $6.01 \pm 0.49$ to $6.09 \pm$ $0.74 \%$ in the fresh okra samples (Table 2). The present value is slightly less compare to the reported values of

Rakesh et al. and Dilip et al. studies, which were 7.12 and $7.45 \%$, respectively. ${ }^{20,26}$

Minerals

Minerals are called micronutrients because the body needs them in smaller amounts than carbohydrate, protein, and fat. Vitamins and minerals play important role to release energy from carbohydrate, protein, and fat but not provide energy (calories). There are 16 essential minerals included $\mathrm{Fe}, \mathrm{Cu}$ and $\mathrm{Zn}$. The okra fruit samples were analyzed by atomic absorption spectrometer in BCSIR. Percentage of $\mathrm{Fe}, \mathrm{Cu}$ and $\mathrm{Zn}$ were found to be $11.38-11.43,1.78-1.85$ and $8.63-9.05 \mathrm{mg}$ per $100 \mathrm{~g}$ samples, respectively (Table 2 ). The Iron is a key element in the metabolism of all living organisms. Zinc has a role to cell division, cell growth, wound healing, and the breakdown of carbohydrates. Copper has a role in energy production and helps the body form collagen and absorb iron. The trace mineral content 
( $\mathrm{Fe}, \mathrm{Cu}$ and $\mathrm{Zn}$ ) of okra fruit was found to be matched very well with those values reported by Makhadmeh et al. ${ }^{28}$

\section{Fatty Acids}

The relative percentage of fatty acids (Table 2) were found to be palmitic $0.27-1.35$, cis-9-oleic $3.78-6.32$, linoleic 30.67-38.44, linolenic $2.13-4.85$ and arachidic acid 1.29 $3.17 \%$. Rokayya et al. reported the fatty acid composition in okra pod as palmitic acid (29.18 - $43.26 \%)$, oleic acid $(4.31-6.98 \%)$, linoleic acid (32.22 - $43.07 \%)$, linolenic acid $(6.79-12.34 \%)$ and arachidic acid (ND - $3.48 \%)$ and these are close enough to our findings in the analyzed samples (Table 2) except palmitic acid. ${ }^{29}$

\section{Conclusion}

Okra fruit samples from four local markets in Dhaka city were analyzed for determination of physicochemical properties and pesticide residues. Fresh okra fruits were found to contain moisture above $80 \%$ and ash content $2 \%$. The mean values of total carbohydrates and soluble dietary fiber in okra fruits were $6.01 \pm 0.49$ to $6.09 \pm 0.74 \%$ and $3.40 \pm 0.05$ to $3.46 \pm 0.04 \%$, respectively. It's concluded that insoluble fibers amount in okra fruits were higher than soluble fiber. The relative percentage range of five fatty acids in okra fruits was found to be palmitic acid, cis-9oleic acid, linoleic acid, linolenic acid and arachidic acid in a range of $0.27-1.35,3.78-6.32,30.67-38.44,2.13-4.85$ and $1.29-3.17 \%$, respectively. Micro-minerals (iron, copper and zinc) in okra fruit play vital role in metabolism, red blood cell formation, cell growth and other activity in human body. The amount of iron, copper and zinc was found to be 11.41-11.43, 1.17-1.85 and 8.56-9.05\%, respectively. Total carbohydrates, soluble dietary fiber, minerals and fatty acids were found to be present in okra fruit which are beneficiary for human health and diet. Pesticide residues (Diazinon, chlorpyrifos, fenvalerate, cypermethrin and quinalphos) were found to be absent in okra fruit. So there is a less possibility of the uses of target pesticides during the cultivation of okra fruits. Due to short half-life, the target pesticides might be degraded to various types of persistent or non-persistent compounds. The present study of physicochemical properties of okra fruit samples can be creating an important role to enrich the nutrition table available in Bangladesh.

\section{Acknowledgements}

The authors are grateful to International Science Program (ISP), Uppsala University for financial support.

\section{References}

1. Naveed, A., A. A., Khan, and I.A., Khan, 2009. Generation mean analysis of water stress tolerance in okra (Abelmoschus esculentus L.). Pak. J. Bot., 41, 195-205.

2. Gemede, H. F., N., Ratta, G. D., Haki, and Z., Ashagrie , 2014. Nutritional Quality and Health Benefits of Okra (Abelmoschus Esculentus): A Review. Global J. Med. Res., $\mathrm{K}, 14$ (5, version 1.0), 28-37.
3. Gemede, H.F., N., Ratta, G.D., Haki, A.Z., Woldegiorgis, F., Beyene, 2015. Nutritional Quality and Health Benefits of Okra (Abelmoschus esculentus): A Review. J Food Process. Technol., 6(6), 458.

4. Oyelade, O.J., B.I.O., Ade-Omowaye, and V.F., Adeomi, 2003. Influence of variety on protein, fat contents and some physical characteristics of okra seeds. J. Food Eng., 57, 111114.

5. Alam, A. K. M. A., and M. M., Hossain, 2008. Variability of Different Growth Contributing Parameters of Some Okra (Abelmoschus Esculentus L.) Accessions and Their Interrelation Effects on Yield. J. Agric. Rural Dev., 6(1\&2), 25-35.

6. Rubatzky, V.E., and M., Yamaguchi, 1997. World vegetables: Principles, Production, and Nutritive Values. Chapman and Hall, New York, USA.

7. Mihretu, Y., G., Wayessa, and D., Adugna, 2014. Multivariate Analysis among Okra (A. esculentus L.) Moench) Collection in South Western Ethiopia. J. Plant Sci., 9(2), 43-50.

8. Ndunguru, J., and A.C., Rajabu, 2004. Effect of okra mosaic virus disease on the above-ground morphological yield components of okra in Tanzania. Scienta Horti., 99, 225-235.

9. Maramag, R. P., 2013. Diuretic potential of Capsicum frutescens L., Corchorus oliturius L., and Abelmoschus esculentus L. Asian J. of Natural and App. Sci, 2 (1), 60-69.

10. Jiménez-Escrig, A., and F. J., Sánchez-Muniz, 2000. Dietary fibre from edible seaweeds: Chem. structure, physicochemical Properties and effects on cholesterol metabolism. Nutr. Res., 20(4), 585-598.

11. Gemede, H. F., N., Ratta, G.D., Haki, Z.A.,Woldegiorgis and F. Beyene., 2015. Nutr. Quality and Health Ben. of "Okra" (A. esculentus): A Review. Int. J. Nutr. Food Sci. 4 (2), 208-215.

12. Darmstadt, G. L., M., Mao-Qiang., E., Chi., S.K., Saha, V.A.,Ziboh, R.E. Black, M., Santosham and P.M., Elias., 2002. Impact of tropical oils on the skin barrier: possible implications for neonatal health in devel. Countries. Act. Paediatr, 91 (5), 546-554.

13. William., E. C., 2000. Importance of $n-3$ fatty acids in health and disease. Amer. J. Clin. Nutr., 71, 171S-175S.

14. Adetuyi, F., L., Ajala, and T., Ibrahim, 2012. Effect of the addition of defatted "Okra" seed (Abelmoschus esculentus) flour on the chemical composition, functional properties and $\mathrm{Zn}$ bioavailability of plantain (Musa paradisiacal Linn) flour. JMBFS., 2 (1), 69-82.

15. Passosi, M.E.A, C.F.F., Moreira., M. T. B., Pacheco., I. Takase., M.L. M. Lopes., and V.L. Valente-Mesquita., 2013. Proximate and mineral composition of industrialized biscuits. Food Sci. Technol., 33(2), 323-331.

16. Sultana, A., M. S Haque., M., Shoeb, M.S., Islam, M.I.R., Mamun and N., Nahar, 2012. Presence of yellow 6, an artificial colour additive in orange juice. J. Bangladesh Chem. Soc., 25(1), 80-86.

17. Gemede, H.F., G.D., Haki, F., Beyene, and Z., Ashagrie,A. Z., Woldegiorgis and S. K. Rakshit, 2016. Proximate, 
mineral, and antinutrient compositions of indigenous Okra (Abelmoschus esculentus) pod accessions: implications for mineral bioavailability. Food Sci. Nutri., 4(2), 223-233.

18. Bangash, J.A., M., Arif, F., Khan, Amin-Ur-Rahman and I., Hussain, 2011. Proximate Composition, Minerals and Vitamins Content of Selected Vegetables Grown in Peshawar. J.Chem.Soc.Pak., 33 (1), 118-122.

19. Eze, J.I., and P.I., Akubor, 2012. Effect of Drying Methods and Storage on the Physicochemical Properties of Okra. $J$ Food Process. Technol., 3,177.

20. Chanchal, D.K., S., Alok, M., Kumar, R.K., Bijauliya, S., Rashi, and S., Gupta, 2018. A brief review on Abelmoschus esculentus linn. Okra. IJPSR., 9(1), 58-66.

21. Uyoh, E. A., E. E., Ita, and G. E., Nwofia. 2013. Evaluation of the chemical composition of Tetrapleura tetraptera (Schum and Thonn.) Tuab. accessions from Cross River State, Nigeria. Int. J. Med. Aromati. Plants. 3, 386-394.

22. Nwachukwu, E.C., R., Nulit, and R., Go., 2014. Nutritional and biochemical properties of Malaysian okra variety. Adv. Med. Plant Res. 2(1), 16-19.

23. Etaware,P.M., and E.U., Etaware, 2019. The Effects of Food Processing Techniques on Nutrient Composition of Okra (Abelmoschus Esculentus L. Moench). Int. J. Innov. Res. Adv. Stud. (IJIRAS). 6(10). 90-94.
24. Nnamani, C. V., H. O. Oselebe, and A. Agbautu., 2009. Assessment of nutritional values of three underutilized indigenous leafy vegetables of Ebonyi state, Nigeria. Afr. $J$. Biotechnol. 8, 2321-2324.

25. Omotosho, O. T. 2005. Nutritional quality, functional properties and anti-nutrient compositions of the Larva of Cirinda forda (Westwood) (Lepidoptera:saturniidae). $J$. Zhejiang Univ. Sci. 7, 51-55.

26. Sindhu, R.K., and V., Puri, 2016. Phytochemical, Nutritional and Pharmacological evidences for Abelmoschus esculentus (L.). J Phytopharmacol. 5(6), 238-241.

27. Ikewuchi, C.C., and J.C., Ikewuchi, 2008. Chemical profile of Pleurotus tuberregium (Fr) Sing's Sclerotia Pacific. J. Sci. Technol. 10(1), 295-299.

28. Makhadmeh, I. M. \& Khalil, I., Ereifej, 2004. Geometric Characteristics and Chemical Composition of Okra (Hibiscus esculentus L.) Grown Under Semi-arid Conditions. Int. J. Food Prop., 7(1), 83-90.

29. Sami, R., J., Lianzhou, L., Yang, Y., Ma., and J., Jing, 2013. Evaluation of Fatty Acid and Amino Acid Compositions in Okra (Abelmoschus esculentus) Grown in Different Geographical Locations. BioMed Research International, Article ID 574283, 6 pages. http://dx.doi.org/10.1155/2013/574283. 